\author{
M. Balanou, E. 1. Papazoglou, A. P. Markopoulos, Athens, Greece, \\ P. Karmiris-Obratański, Cracow, Poland

\section{EXPERIMENTAL INVESTIGATION OF SURFACE TOPOGRAPHY OF AL7075-T6 ALLOY MACHINED BY EDM}

\begin{abstract}
Electrical discharge machining is one of the most important non-conventional machining processes for removing material from electrically conductive materials by the use of controlled electric discharges. EDM is a non-contact machining process, therefore, is free from mechanical stresses. This paper investigates the machining Al7075-T6 alloy by EDM using a copper electrode. Al7075-T6 alloy was selected, because of its growing use in a lot of engineering applications. The effect of electrical parameters, peak current and pulse-on time, on the surface integrity, was studied. Area surface roughness parameters (arithmetical mean height, Sa, and maximum height, Sz) were measured on all samples and $3 D$ surface characterization has been carried out with confocal laser scanning microscopy. The experimental results showed that the surface roughness is mainly affected by the pulse-on time.
\end{abstract}

Keywords: Electrical discharge machining; Aluminum alloys; Surface topography; Surface roughness; Peak current; Pulse-on time.

\title{
Introduction
}

Electrical discharge machining (EDM) is one of the most important nonconventional manufacturing processes and is used for machining with high precision and accuracy electrically conductive materials which are difficult to machine by conventional machining processes. EDM finds extensive use in many engineering applications like machining surgical components, dies and moldmaking, and in automobile and aerospace industries [1], [2].

$\mathrm{EDM}$ is a thermo-electric process and characterized by an erosion effect produced when electrical discharges occurred between two conductive electrodes. In this process, when a voltage difference is applied between the electrode and the workpiece, which are separated by a dielectric fluid, causes the formation of an electric discharge. The electric discharge generates high temperatures $(6000-$ $12000{ }^{\circ} \mathrm{C}$ ) and leads to melting of the material at the point of discharge. [3]. The melted material is removed from the tool electrode and the workpiece, and as a result a small crater is created on both surfaces. The molten material which had not been efficiently flushed away by the dielectric fluid is re-solidified in the crater, forming a white layer.

The literature shows that a lot of works have been carried out for the machining of hard materials such as tool steels, tungsten and ceramics. However, lately, soft materials like aluminum alloys have been machined by EDM as well. Aluminum alloys have been widely used in a lot of industries like marine,

(C) M. Balanou, E. l. Papazoglou, A. P. Markopoulos, P. Karmiris-Obratański, 2021 
aerospace, automotive and electrical equipment. Above all aluminum alloys, the $7 \mathrm{xxx}$ series (also called aluminum- zinc alloy) is the strongest wrought aluminum alloys series with a better response to age hardening, obtaining better mechanical properties [4].

The studies in the EDM machining of aluminum $7 \mathrm{xxx}$ alloys have been focused on machining performance parameters such as material removal rate (MRR), tool wear rate (TWR) and the machined surface quality (SQ). Gatto et al. [5] studied the machinability of Al2219-T6, Al7050-T6 and Al7075-T6 with EDM. Surface roughness, dimensional and accuracy of the workpieces and the wear mechanism of the electrodes were evaluated. Kasman and Tosun [6] conducted experiments for AA7075 aluminum alloy under different process parameters peak current, pulse-on time, pulse-off time, gap voltage and using copper and graphite electrode. Taguchi method was used to design the experiment. Routara et al. [7] analyzed MRR, TWR and SR on T6-Al 7075 alloy using Cu tool in steady and rotary conditions. For conducting experiments, spark gap, pulse-off time and peak current was selected as machining parameters. Furthermore, a few of works have been carried out on machining $\mathrm{Al}$ alloy 7075 as a base matrix alloy in composite materials by EDM. Some examples of AMCs machined by EDM are Al7075-B $\mathrm{B}_{4} \mathrm{C}$

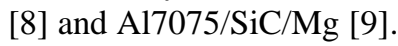

The present study investigates the machining of aluminum alloy Al7075-T6 with EDM by using a copper electrode. A17075-T6 is a high strength engineering alloy, which is used as structural material in marine, automotive and aviation applications, while it is suitable for use in injection moulds applications. The effect of peak current and pulse-on time on the Surface Roughness (SR) was studied. The surface characteristics were also evaluated by confocal laser scanning microscopy.

\section{Experimental procedure}

Experiments were conducted on a die-sinking EDM machine (ANGIETRON EMT 1.10). Aluminum alloy Al7075-T6 was machined by EDM using a rectangular copper electrode with dimensions of $38 \times 23 \mathrm{~mm}$. The chemical composition, density and hardness of Al7075-T6 are shown in Table 1. A hydrocarbon mineral oil was used as a dielectric fluid. The selected input parameters are given in Table 2. Peak current and pulse-on time were used to investigate the effect of surface roughness. The selected input parameters are given in Table 2. In all experiments, straight polarity was used, with 100 and $30 \mathrm{~V}$ as the open and close circuit voltage, respectively. Moreover, the dielectric fluid flushing pressure was constant for all the experiments, while the duty cycle was automatically adjusted by the machine, for optimized machining efficiency. The duty cycle $(\eta)$ is calculated by using Equation (1): 


$$
\eta=\frac{\overline{I_{p}}}{I_{p}}
$$

with $\overline{I_{p}}$ the ammeter indication of the mean current intensity in $A$, and $I_{p}$ the pulse current in A.

Table 1 - Chemical composition, density and hardness of Al-7075 T6 (wt.\%)

\begin{tabular}{|c|c|c|c|c|c|c|c|c|c|c|}
\hline $\mathbf{Z n}$ & $\mathbf{S i}$ & $\mathbf{F e}$ & $\mathbf{T i}$ & $\mathbf{C u}$ & $\mathbf{M n}$ & $\mathbf{M g}$ & $\mathbf{C r}$ & Other & $\begin{array}{c}\text { Density } \\
\left(\mathbf{g} / \mathbf{m m}^{\mathbf{3}}\right)\end{array}$ & $\begin{array}{c}\text { Hardness } \\
(\mathbf{H V})\end{array}$ \\
\hline $\begin{array}{r}5.1- \\
6.1\end{array}$ & 0.40 & 0.50 & 0.20 & $\begin{array}{c}1.2- \\
2.0\end{array}$ & 0.30 & $\begin{array}{c}2.1- \\
2.9\end{array}$ & $\begin{array}{r}0.18- \\
0.28\end{array}$ & 0.65 & 0.00281 & 175 \\
\hline
\end{tabular}

Table 2 - Input parameters

\begin{tabular}{|c|c|}
\hline Parameters & \\
\hline Peak Current $\left(\mathbf{I}_{\mathbf{p}}\right)$ & $15,18,21$ and $24 \mathrm{~A}$ \\
\hline Pulse-on duration $\left(\mathbf{T}_{\mathbf{o n}}\right)$ & $100,200,300$ and $500 \mu \mathrm{s}$ \\
\hline Open-circuit voltage & $100 \mathrm{~V}$ \\
\hline Close-circuit voltage & $30 \mathrm{~V}$ \\
\hline Polarity & Straight \\
\hline Dielectric Fluid & Hydrocarbon mineral oil \\
\hline
\end{tabular}

SR of the machined surface is measured on random surface area by TOPO 01P contact profilometer by using the ISO 25178-2 to analyze the collected data. The cut-off length was set at $2.5 \mathrm{~mm}$ with a cutting length of $8 \mathrm{~mm}$. In this present study, the following surface roughness parameters have been taken:

- $\mathrm{S}_{\mathrm{a}}$ is the arithmetical mean of the difference in height within a definition area (A) and calculated using Equation (2)

$$
\mathrm{S}_{\mathrm{a}}=\frac{1}{\mathrm{~A}} \iint_{\mathrm{A}}|\mathrm{z}(\mathrm{x}, \mathrm{y})| \mathrm{dxdy}
$$

- $\mathrm{S}_{\mathrm{z}}$ is the sum of the largest peak height value and the largest pit depth value within the defined area.

The confocal laser scanning microscopy (CLSM) was used to study the machined surface characteristics. To measure the slot dimensions, a VHX-6000 ultra-deep-field microscope (KEYENCE, Mechelen, Belgium) was used, which is based on Focus Variation Microscopy Microscopy (FVM), equipped with a 202000x objective. After the experiments were conducted, 3D surfaces was generated. The results of surface roughness parameters are shown in Table 3. 
Table 3 - Experimental results

\begin{tabular}{|c|c|c|c|}
\hline $\mathbf{I}_{\mathbf{p}}(\mathbf{A})$ & $\mathbf{T}_{\mathrm{on}}(\boldsymbol{\mu s})$ & $\mathbf{S}_{\mathbf{a}}(\boldsymbol{\mu m})$ & $\mathbf{S}_{\mathbf{z}}(\boldsymbol{\mu m})$ \\
\hline 15 & 100 & 9.83 & 68.8 \\
\hline 18 & 100 & 9.03 & 68.55 \\
\hline 21 & 100 & 8.5 & 83.83 \\
\hline 24 & 100 & 9.97 & 78.7 \\
\hline 15 & 200 & 11.69 & 103.1 \\
\hline 18 & 200 & 13.19 & 98.03 \\
\hline 21 & 200 & 14.11 & 109.41 \\
\hline 24 & 200 & 15.33 & 134.57 \\
\hline 15 & 300 & 14.54 & 114.89 \\
\hline 18 & 300 & 16.88 & 118.75 \\
\hline 21 & 300 & 17.76 & 130.85 \\
\hline 24 & 300 & 17.97 & 150.3 \\
\hline 15 & 500 & 18.21 & 147.75 \\
\hline 18 & 500 & 19.88 & 128.55 \\
\hline 21 & 500 & 17.27 & 143.27 \\
\hline 24 & 500 & 20.09 & 162.77 \\
\hline
\end{tabular}

\section{Results and Discussion}

\section{Surface Roughness}

$\mathrm{SR}$ is one of the most major performance measures in EDM and is influenced by the machining parameters. The machined surface obtained by EDM is the result of the amount of energy released during the process which causes material removal. The discharge energy is affected by the machining parameters. Therefore, peak current and pulse-on time are the major factors that affect the surface roughness. Surface roughness increases with an increase in peak current and pulse-on time, due to the increase in thermal energy which transferred to the machined surface [10], [11]. This can be explained by the fact that, as pulse-on time gets higher, the plasma column expands beyond the point of electrical discharge, leading to a larger diameter crater, on the other hand, the peak current influences the depth of the crater [1]. Thus, the amount of the molten material is increased. If this molten material is not flushed away by the dielectric fluid, it will re-solidify on the machined surface and form a white layer. The surface roughness is also influenced by the white layer formation [11]. 
In Figure 1 the main effect plots and the interaction plots for the $S_{a}$ parameters are presented. In general, from the main effect plot it can be observed that the peak current does not have a significant effect on $\mathrm{S}_{\mathrm{a}}$. On the other hand, an increase in pulse-on time results in an increase in $S_{a}$. Particularly, $S_{a}$ increased up to $50.8 \%$ as the pulse-on time increased from 100 to $500 \mu \mathrm{s}$. The interaction plot confirms those results. It is observed that as the $T_{o n}$ is increased, $S_{a}$ is getting higher values in re respect of peak current.
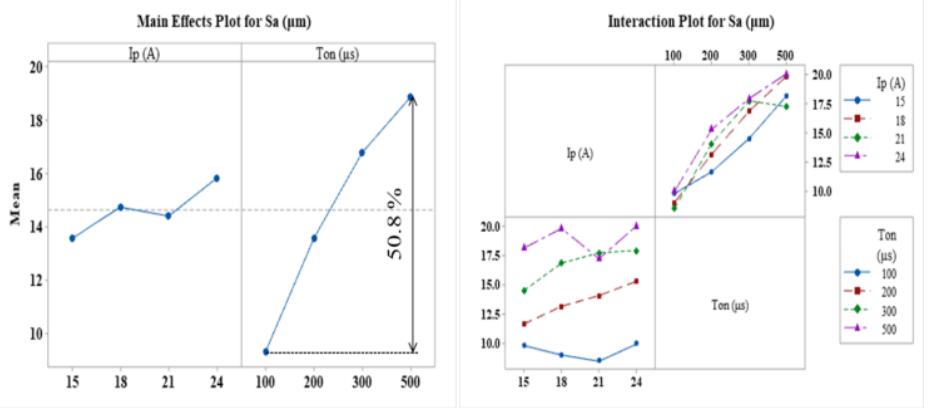

Figure 1 - Main effect plot and interaction plot for Sa

The main effect plots and the interaction plots for the $\mathrm{Sz}$ parameters are illustrated in Figure 2. The peak current plot in the main effect diagram shows reduce in $S_{z}$ up to $18 \mathrm{~A}$, followed by an increase of $S_{z}$ as the peak current gets higher at 24A. At the same time, as the pulse-on time increased an increase up $57.9 \%$ in the $S_{z}$ take place. From the interaction plot it can be concluded that as the $\mathrm{T}_{\text {on }}$ is increased, $\mathrm{Sz}$ is increased in respect of peak current.
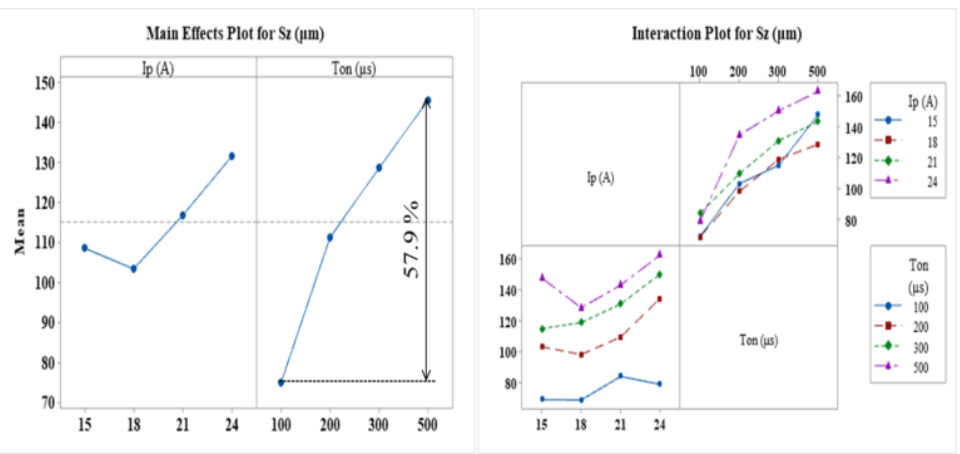

Figure 2 - Main effect and interaction plot for $\mathrm{S}_{\mathrm{z}}$ 


\section{Surface Topography}

As has been stated above, the topography of the machined surface is due to the enormous amount of heat generated by the discharges. After the EDM, the condition of the surface is changed due to erosion and vaporization of the material from both the electrodes followed by re-solidification. The machined surface is characterized by the presence of a distribution of overlapping craters with irregular flow marks of molten metal and debris particles. The size of the craters produced affected by the machining parameters and consequently peak current and pulse-on time influence the surface topography.

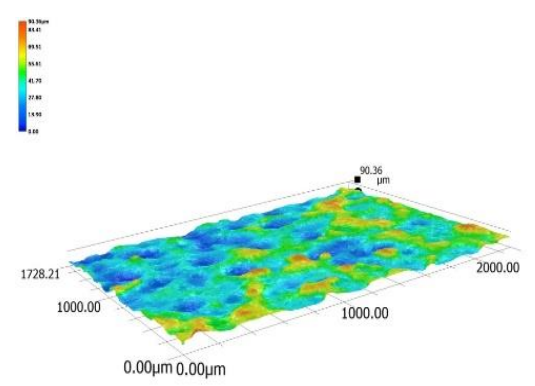

(a)

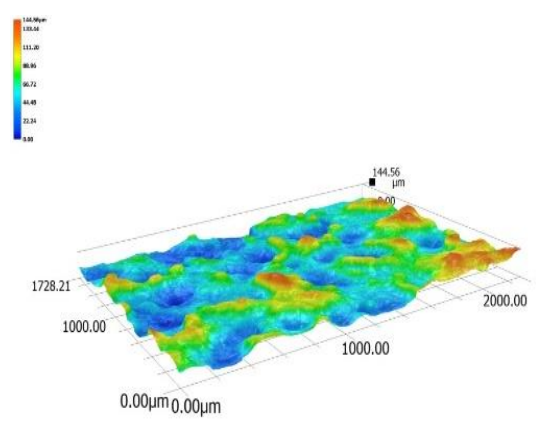

(c)

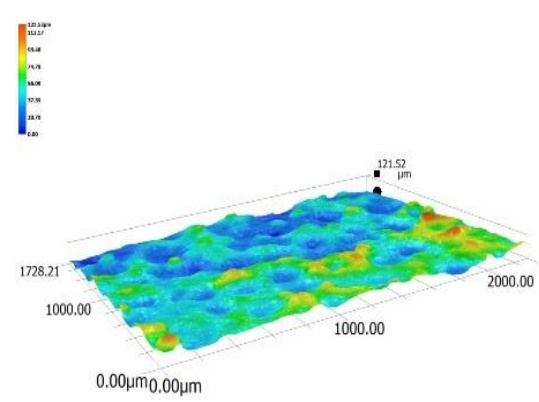

(b)
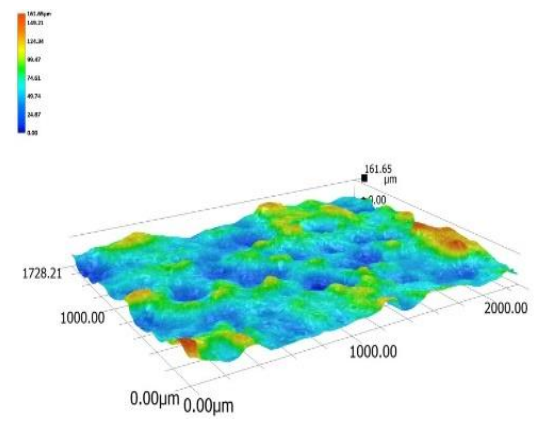

(d)

Figure 3 - Surface topography of the machined surface for (a) $\mathrm{I}_{\mathrm{p}}=18 \mathrm{~A}$ and $\mathrm{T}_{\mathrm{on}}=100 \mu \mathrm{s}$, (b) $\mathrm{I}_{\mathrm{p}}=15 \mathrm{~A}$ and $\mathrm{T}_{\text {on }}=200 \mu \mathrm{s}$,

(c) $\mathrm{I}_{\mathrm{p}}=21 \mathrm{~A}$ and $\mathrm{T}_{\mathrm{on}}=100 \mu \mathrm{s}$ and (d) $\mathrm{I}_{\mathrm{p}}=24 \mathrm{~A}$ and $\mathrm{T}_{\mathrm{on}}=500 \mu \mathrm{s}$ 
The 3-D image in Figs. 3 presents the variation of the machined surface for different machining parameters from the analysis of CLSM. The machined surface is covered with a distribution of craters and as well as solidified crater boundaries. As discharge energy increased, the sizes of the craters are changing and become more distinct. The images showed that the height difference between the base of the crater and the white layer has been increased. Thus, surface roughness and surface height inhomogeneity increased as the machining parameters changing. These results are agreed with the surface roughness measurements. The $S_{a}$ and $S_{z}$ take higher values under more intense conditions. This can be confirmed and by the 3-D images, the machined surface becomes rougher as the peak current and pulse-on time get higher values.

\section{Conclusion}

This paper presented an experimental study on the surface integrity of A17075-T6 alloy, machined EDM. The studied machining parameters were the pulse current $\left(\mathrm{I}_{\mathrm{p}}\right)$ and the pulse-on time $\left(\mathrm{T}_{\mathrm{on}}\right)$. The surface topography was studied through roughness measurements $\left(S_{\mathrm{a}}\right.$ and $\left.S_{\mathrm{z}}\right)$ and confocal laser scanning microscopy. From the experimental results, the conclusions are summarized as follows:

- The $S_{a}$ is strongly affected by the pulse-on time. The mean value of Sa increased up to $50.8 \%$ as the pulse-on time increased from 100 to $500 \mu \mathrm{s}$.

- $\quad$ The $S_{z}$ significantly increased for an increase in pulse-on current from 100 to $500 \mu \mathrm{s}$.

- From the CLSM the morphology of the machined was observed. . The size of the craters produced affected by the machining parameters and become more distinct when the thermal is increased.

References: 1. Muhammad Pervej Jahan, Ed., Electrical Discharge Machining (EDM): Types, Technologies and Applications. New York: Nova Science Publishers, 2015. 2. M. Niamat, S. Sarfraz, E. Shehab, S. O. Ismail, and Q. S. Khalid, "Experimental Characterization of Electrical Discharge Machining of Aluminum 6061 T6 Alloy using Different Dielectrics," Arab. J. Sci. Eng., vol. 44, no. 9, pp. 8043-8052, 2019, doi: 10.1007/s13369-019-03987-4. 3. K. H. Ho and S. T. Newman, "State of the art electrical discharge machining (EDM)," Int. J. Mach. Tools Manuf., vol. 43, no. 13, pp. 1287-1300, 2003, doi: 10.1016/S0890-6955(03)00162-7. 4. K. Dehghani, A. Nekahi, and M. A. M. Mirzaie, "Optimizing the bake hardening behavior of A17075 using response surface methodology," Mater. Des., vol. 31, no. 4, pp. 1768-1775, 2010, doi: 10.1016/j.matdes.2009.11.014. 5. A. Gatto, E. Bassoli, and L. Iuliano, "Performance Optimization in Machining of Aluminium Alloys for Moulds Production: HSM and EDM," Alum. Alloy. Theory Appl., 2011, doi: 10.5772/14847. 6. Kasman and N. Tosun, "Investigation of surface roughness in machining of aluminum alloy with EDM," no. May, pp. 101-104, 2015. 7. B. C. Routara, D. Das, M. P. Satpathy, B. K. Nanda, A. K. Sahoo, and S. S. Singh, "Investigation on machining characteristics of T6-A17075 during EDM with $\mathrm{Cu}$ tool in steady and rotary mode," Mater. Today Proc., vol. 26, pp. 2143-2150, 2019, doi: 10.1016/j.matpr.2020.02.462. 8. S. Gopalakannan, T. Senthilvelan, and S. Ranganathan, "Modeling and optimization of EDM process parameters on machining of Al7075-B4C MMC using RSM," Procedia Eng., vol. 38, pp. 685-690, 
2012, doi: 10.1016/j.proeng.2012.06.086. 9. P. Malhotra, R. K. Tyagi, N. K. Singh, and B. S. Sikarwar, "Experimental investigation and effects of process parameters on EDM of A17075/SiC composite reinforced with magnesium particles," Mater. Today Proc., vol. 21, pp. 1496-1501, 2020, doi: 10.1016/j.matpr.2019.11.069. 10. S. Kar, S. Chakraborty, V. Dey, and S. K. Ghosh, "Optimization of Surface Roughness Parameters of Al-6351 Alloy in EDC Process: A Taguchi Coupled Fuzzy Logic Approach," J. Inst. Eng. Ser. C, vol. 98, no. 5, pp. 607-618, 2017, doi: 10.1007/s40032-016-0297-y. 11. H. T. Lee and T. Y. Tai, "Relationship between EDM parameters and surface crack formation," J. Mater. Process. Technol., vol. 142, no. 3, pp. 676-683, 2003, doi: 10.1016/S0924-0136(03)00688-5.

\title{
Марія Балану, Емануїл Л. Папазоглу, Ангелос П. Маркопулос, Афіни, Греція, Панагіотіс Карміріс-Обратанські, Краків, Польща \\ ЕКСПЕРИМЕНТАЛЬНЕ ДОСЛІДЖЕННЯ РЕЛЬЕФУ ПОВЕРХНІ СПЛАВУ АL7075-Т6, ОБРОБЛЕНОГО ЕЛЕКТРОЕРОЗІЙНИМ МЕТОДОМ
}

\begin{abstract}
Анотація. Електроерозійна обробка (ЕEО) $\epsilon$ одним з найбільи важливих нетрадиційних виробничих прочесів і використовується для обробки з високою точністю електропровідних матеріалів, які важко обробляти звичайними процесами обробки. ЕEО знаходить иироке застосування в багатьох інженерних додатках, таких як обробка хірургічних компонентів, штампів та виготовлення прес-форм, а також в автомобільній і аерокосмічній промисловості. Останнім часом за допомогою електроерозійної обробки обробляються також м'які матеріали, такі як алюмінієві сплави, які широко використовуються в багатьох галузях промисловості, таких як морське, аерокосмічне, автомобільне та електричне обладнання. 3 усіх алюмінієвих сплавів серія 7хxх (яка також має назву алюмінієво-иинковий сплав) є найміцнішою серією алюмінієвих сплавів які підлягають деформаиї з кращими показниками на старіння $i$ поліпшеними механічними властивостями. У цій статті досліджується обробка алюмінієвого сплаву Al7075-T6 за допомогою ЕEО з використанням мідного електрода. Al7075-T6 - це високоміцний сплав, який використовується в якості конструкиійного матеріалу в морських, автомобільних $і$ авіаційних виробництвах, а також підходить для використання в ливарних формах. Було вивчено вплив пікового струму і тривалості імпульсу на шорсткість поверхні (SR). Характеристики поверхні також оцінювали за допомогою конфокальної лазерної сканувальної мікроскопіі. Загалом, можна помітити, що піковий струм не має значного впливу на Sa. 3 іншого боку, збільшення часу включення призводить до збільшення Sa. Зокрема, Sа збільшився до 50,8\% при збільшенні часу імпульсу від 100 до 500 мкс. Оброблена поверхня характеризується наявністю розподілу кратерів, які перекриваються, з нерівномірними слідами течії розплавленого металу і частинок відходів. Розмір утворених кратерів залежить від параметрів обробки і, отже, піковий струм і час імпульсу впливають на топографію поверхні.
\end{abstract}

Ключові слова: електроерозійна обробка; алюмінієві сплави; топографія поверхні; шорсткість поверхні; піковий струм; тривалість імпульсу. 